\title{
Peningkatan Kualitas Pembelajaran Online melalui Strategi Komunikasi Efektif Selama Pandemi Covid-19
}

\author{
Afifah Fatihakun Ni'mah Wahidah ${ }^{凶}{ }_{1}$, Naimah $^{2}$, Dian Tri Utami ${ }^{3}$ \\ Pendidikan Islam Anak Usia Dini, Universitas Islam Negeri Sunan Kalijaga Yogyakarta, \\ Indonesia( ${ }^{(1)}$ \\ DOI: $\underline{10.31004 / o b s e s i . v 6 i 4.1615}$
}

\begin{abstract}
Abstrak
Penelitian ini dilakukan untuk menganalisis dan memaparkan bagaimana strategi komunikasi antara dosen dengan mahasiswa dalam mengatasi hambatan mengikuti perkuliahan online. Peneliti menerapkan pendekatan kualitatif dengan metode studi kasus, penelitian ini melibatkan satu orang dosen pengampu dan mahasiswanya yang berjumlah 30 anak dari UIN Syarif Kasim Riau, Jurusan PIAUD, mata kuliah Asesmen Pembelajaran RA. Hasil dari penelitian menunjukkan selama proses pembelajaran online, mahasiswa mendapat kesulitan untuk mengerti dari materi yang dijelaskan oleh dosen, dan komunikasi yang baik menjadi kunci utamanya, dosen dan mahasiwa yang mempunyai jalinan komunikasi yang baik yaitu dengan menggunakan strategi kolaborasi antara dosen dan mahasiswa sehingga akan menghasilkan proses penyampaian pengetahuan secara online menjadi maksimal. Dalam hal ini didukung dengan dosen yang secara optimal menciptakan proses pembelajaran yang aktif, inovatif dan variatif, serta dosen memposisikan diri sebagai motivator dan inisiator agar mahasiswa semakin semangat dalam mengikuti pembelajaran online.
\end{abstract}

Kata Kunci: strategi komunikasi; pembelajaran; online.

\begin{abstract}
This study was conducted to analyze and explain how the effectiveness of communication strategies between lecturers and students in order to overcome obstacles to participating in online lectures. The researcher applies a qualitative approach with a case study method, This study involved one supervisor and 30 students from UIN Syarif Kasim Riau, PIAUD major, RA Learning Assessment course. The results of the study show that during the online learning process, students have difficulty understanding the material explained by the lecturer, and good communication is the main key, lecturers and students who have a good communication network are using a collaborative strategy between lecturers and students so that it will produce the process of delivering knowledge online is maximized. In this case, it is supported by lecturers who optimally create an active, innovative and varied learning process, and lecturers must position themselves as motivators and initiators so that students are more enthusiastic in participating in online learning.
\end{abstract}

Keywords: communication strategy; learning; online

Copyright (c) 2021 Afifah Fatihakun Ni'mah Wahidah, Naimah, Dian Tri Utami

$\triangle$ Corresponding author :

Email Address Author 1: 19204032012@student.uin-suka.ac.id (Yogyakarta, Indonesia)

Received 7 July 2021, Accepted 13 December 2021, Published 27 February 2022 


\section{PENDAHULUAN}

Coronavirus Diseases 2019 atau sering masyarakat menyebutnya Covid-19 menjadi yang menjadi sorotan baru dalam bidang kesehatan hingga dalam semua lapisan masyarakat umum. Semakin hari Covid-19 membuat resah masyarakat, karena mudah dan cepatnya virus ini menyebar, dampak yang serius terjadi dalam dunia pendidikan Indonesia. Jika awalnya proses pendidikan dapat dilakukan dengan langsung bertatap muka, maka kini hanya dapat dilakukan secara online. Kegiatan pembelajaran online dilakukan melalui berbagai aplikasi yang mendukung untuk membantu siswa agar tetap bisa melaksanakan pembelajaran dengan para guru mereka. Untuk jenjang perguruan tinngi, hal ini menjadi salah satu langkah yang harus ditempuh untuk bersaing di era revolusi industri sekaligus memberi kesempatan bagi lebih banyak orang untuk memperoleh akses ke pendidikan tinggi.

Pembelajaran online termasuk sebuah proses pembelajaran dalam jaringan yang memanfaatkan internet tanpa bertatap muka secara langsung. Dosen dan mahasiswa berada dalam tempat yang terpisah, hal ini untuk menciptakan interaksi pembelajaran yang fleksibilitas, aksesibilitas, dan konektivitas. Pembelajaran online yang menggunakan jaringan internet ini juga tentunya memiliki kekuatan, hambatan, tantangan, serta dampak positif dan negatif. Akselerasi dan transformasi menjadi dampak positif untuk dunia dunia pendidikan, meningkatkan minat penelitian, seluruh pembelajaran dapat terlaksana dengan beberapa jenis media yang mendukung untuk belajar mengajar online, kegiatan-kegiatan diskusi online mulai muncul dengan akses secara cuma-cuma contoh kegiatannya adalah seminar-seminar yang dilakuakn secara online. (Levine \& Winduwati, 2021)

Strategi komunikasi dalam pendidikan berkaitan dengan komunikasi yang melibatkan dua komponen, yaitu satu pengajar atau pendidik sebagai komunikator dan kedua pelajar atau sisiwa sebagai komunikan (Oktaviana et al., 2019). Jika untuk tingkat paling bawah dan menengah pengajar itu adalah guru, dan pelajar itu adalah siswa, sedangkan untuk tingkat yang lebih tinggi pengajar itu adalah dosen, dan pelajarnya adalah mahasiswa. Tidak ada perbedaan anatara pengajar dan pelajar, hakikatnya mereka adalah sama, hanya saja peran dari masing-masing mereka yang menjadikan jenis pesan serta kualitas yang disampaikan berbeda (Miftah, 2019).

Dalam komunikasi yang efektif, ada bebrapa hal yang harus diperhatikan, yaitu: 1 . Respect, memberikan penghargaan kepada mahasiswa, sekecil apapun itu mahasiswa yang merasa karyanya dihargai akan membuat proses belajar mengajar menjadi sebuah proses yang sangat berharga. 2. Emphaty, perlu saling memahami dan mengerti keberadaan, perilaku, dan keinginan dari mahasiswa. 3. Audible, setiap materi yang disampaikan oleh dosen diterima dan dipahami oleh mahasiswa dengan baik. 4. Clarity, dosen dan mahasiswa perlu mengembangkan sikap terbuka (tidak ada yang ditutupi atau disembunyikan), sehingga dapat menimbulkan rasa percaya (trust). Karena tanpa keterbukaan akan timbul sikap saling curiga dan pada gilirannya akan menurunkan semangat dan antusiasme mahasiswa dalam proses belajar-mengajar. 5. Humble, dengan menghargai orang lain, mau mendengar, menerima kritik, tidak sombong, dan tidak memandang rendah orang lain.(Wisman, 2017)

Dosen dan mahasiswa di dalam menjalankan proses pembelajaran harus bisa berjalan secara praktis atau dapat diterapkan dalam prakteknya juga sewaktu-waktu prosesnya bisa berbeda karena disesuaikan dengan keadaan, seperti keadaan pandemi sekarang ini semua proses pendidikan harus dilakukan secara online. Komunikasi antara dosen dan mahasiswa bisa dikatakan berjalan dengan baik apabila terdapat komponen-komponen spereti: 1 . Knowledge/pengetahuan, maksudnya yaitu pendalaman bahan perkuliahan sepadan dengan bahan materi yang akan diberikan kepada mahasiswa. 2. Sincerity/ketulusan, maksudnya guru atau dosen yang telah menjadi orangtua kedua para siswa dan mahasiswanya, dalam diri dosen sangat diharapkan sebuah kerelaan dan integretas saat membimbing ana-anak didiknya/mahasiswanya, dengan begitu sangat diharapkan akan 
terjadi perubahan perilaku disetiap anak didiknya dengan semakin bertambahnya ilmu pengetahuan yang diperoleh saat sekolah/kampus. Ketulusan saat malakukan tugas sebagai pengajar akan mempermudah jalannya proses transfer pengetahuan kepada anak didik/mahasiswa, karena itu sudah tanggungjawab pengajar untuk penguasaan atas materi yang disampaikan. 3. Enthusiasm/antusias, maksudnya seorang guru/dosen dalam menjalankan tugas dan perannya diperlukan antusias yang penuh dalam melaksankaan tugasnya tersebut, karena antusias yang penuh dari seorang pengajar akan berpengaruh terhadap situasi dan kondisi proses pembelajaran, jika guru atau dosen memulai kelas dengan penuh antusias walaupun dengan system online, hal tersebut juga pasti akan menghasilkan pengaruh baik dan suasana kelas menjadi penuh dengan semangat. 4 . Practice/latihan, maksudnya setiap guru/dosen perlu sekali melakukan latihan, karena jika guru/dosen rutin melaksankan latihan tentunya akan meningkatkan keterampilan mengajarnya.(Vera, 2020)

Setelah membahas pemahaman mengenai komponen yang harus terdapat pada pembelajaran online di era pendemi Covid-19, maka bisa dijelaskan bahwa kualitas terbaik pada pembelajaran bisa berhasil, apabila proses transfer pengetahuan yang dilakukan oleh dosen kepada mahasiswanya dilakukan dengan cara efektif dan dengan memakai cara yang tepat. Antara mahasiswa dan dosen semuanya harus mempunyai peran secara sungguh-sungguh di dalam proses pembelajaran. Dosen dituntut harus kreatif, disiplin dan inovatif saat menyampaikan pembelajaran, dosen juga diharapkan selalu antusias dan tulus dalam menyampaikan pembelajaran, dan mahasiswa sangat diharapkan selalu serius dan aktif dalam belajar, memiliki kesadaran untuk belajar secara independen, dan harus mempunyai kedisiplinan tinggi khususnya saat mengerjakan tugas yang diberikan oleh dosen.

Sayangnya, dengan situasi yang sangat mendesak seperti ini dosen dan mahasiswa belum sepenuhnya siap untuk menjalankan proses pendidikan yang harus dilaksankan dengan cara online. Dalam proses pembelajaran dosen dan mahasiswa dituntut untuk mengerti dan paham bagaimana cara proses belajar dengan online secara cepat, serta diharapkan bisa mempergunakan beberapa aplikasi seperti google meet, zoom atau skype dan jenis-jenis aplikasi lainnya. Namun keadaan di lapangan saat ini dosen dan mahasiswa belum sepenuhnya dapat menggunakan piranti teknologi internet atau media sisoal secara mahir (Yusuf Siregar \& Amiril Akbar, 2020).

Masalah lain muncul seperti komunikasi antara mahasiswa dan dosen yang kurang berjalan dengan baik, terutama dalam menyampaikan materi pembelajaran. Beberapa mahasiswa merasa bingung dengan materi yang telah didapatkan dari dosennya. Walaupun kegiatan pembelajaran telah menggunakan cara videocall, tetapi masih saja beberapa mahasiswa merasakan kurang maksimal dalam menyerap segala ilmu dari dosennya. Selanjutnya, jaringan internet yang belum sepenuhnya merata menjadi kendalan bagi mahasiswa dalam menjalani proses pembelajaran online ini.

Begitu banyaknya permasalahan yang hadir disaat pembelajaran online menjadi ujian sekaligus tantangan tersendiri untuk mahasiswa dan dosen dalam melaksanakan tugas masing-masing, supaya tujuan belajar mengajar bisa tercapai dan tetap terjaganya kualitas output pembelajaran (Jessika Tam ara et al., 2020). Semua masalah dalam pembelajaran online ini bisa selesai bila para dosen mempunyai cara/strategi dan gaya komunikasi tertentu selama proses belajar mengajar online disaat pandemik ini masih berlangsung. Dosen diharuskan dapat memunculkan cara ataupun metode pembelajaran efektif penuh kratif dan berinovatif, dan untuk mahasiswa diharapkan selalu semangat dan aktif di saat proses belajar mengajar online. Pembelajaran yang berpusat kepada mahaiswa saja tidak akan cukup menjamin hasil pembelajaran yang maksimal, diperlukan juga pembelajaran yang memadukan antara pembelajaran yang terpusat pada mahasiswa dan juga terpusat pada dosen, dalam proses belajar mengajar yang bebasis pemecahan masalah dan berbasis proyek (Mutawakkil \& Nuraedah, 2019). 
Berbagai penelitian yang sejenis dengan tema penelitian ini adalah seperti penilitian yang dilakukan oleh Michelle Levine dan Septia Winduwati yang berjudul Strategi Komunikasi Dosen Perguruan Tinggi Swasta dalam Perkuliahan Daring Saat Pandemi Covid-19. Hasil dari penelitiannya yaitu para dosen diharapkan mempunyai cara khusus yang terbaru dalam melaksanakan perkuliahan online. Strategi utama yang digunakan adalah strategi komunikasi, media baru, komunikasi pendidikan, dan pembelajaran jarak jauh. Hasil menunjukkan bahwa dosen melakukan pengawasan terhadap media-media yang digunakan untuk pembelajaran daring, pembelajaran daring juga dipenuhi oleh metode problem based learning, memanfaatkan fitur-fitur yang tersedia, melakukan pengurangan atau penambahan substansi atau bobot tugas dan materi, serta bermain dengan tempo dan intonasi saat berbicara (Levine \& Winduwati, 2021). Dapat dilihat perbedaannya, yaitu pada tempat penelitian yang dilaksanakan di perguruan tinggi swasta. Sedangkan penelitian ini dilaksankan di perguruan tinggi negeri.

Selanjutnya penelitian serupa lainnya yaitu penlitian yang ditulis oleh Kharisma Danang Yuangga dan Denok Sunarsi yang berjudul Pengembangan Media Dan Strategi Pembelajaran Untuk Mengatasi Permasalahan Pembelajaran Jarak Jauh Di Pandemi Covid19. Hasil penelitian menunjukkan masalah proses mengajar jarak jauh secara online di masa pandemi ini, masalah muncul dikarenakan kurang siapnya guru dan siswa dalam menghadapi system baru yang diterapkan, hal tersebut menjadikan para siswa dituntut bisa menyerap ilmu dari materi yang telah tersampaikan dari gurunya, disamping itu para orangtua wali siswa juga harus mengalokasikan pengeluaran ekstra untuk membeli paket data guna dapat mengikuti permbelajaran daring dengan jadwal yang sudah diatur oleh sekolah. Dan guru juga dituntut dapat menyampaikan materi kepada para sisiwa dengan cara yang kreatif dan efektif, sehingga dapat diakses melalui jarak jauh (Yuangga \& Sunarsi, 2020). Untuk penelitian rujukan yang kedua ini perbedaannya terletak pada subjek penelitiannya yaitu adanya Sekolah Dasar. Sedangkan penelitian ini subjeknya dalah di Perguruan Tinggi.

Penelitian yang serupa selanjutnya dilakukan oleh Rama Kertamukti dengan judul Strategi Komunikasi Antarpribadi Dosen dan Mahasiswa dalam Pengembangan Jiwa Kreatif. Berbagai metode dan strategi pembelajaran dilakukan untuk meningkatkan dan mengembangkan semangat kreatif seorang mahasiswa. Komunikasi hubungan manusia memegang peran yang sangat penting dalam strategi pengembangan kreativitas. Pola komunikasi ini mampu berkembang kreativitas mahasiswa, karena selain mahasiswa mendapat pola pengawasan dosen untuk aktif dan selalu berkomunikasi dengan dosen dan dengan temannya, baik saat kuliah dan saat menyelesaikan tugas lainnya. Melalui komunikasi antarpribadi ini dosen dapat menciptakan kedekatan emosional dengan setiap mahasiswa, sehingga dosen dapat memahami kebutuhan dari mahasiswa didiknya (Kertamukti, 2013). Perbedaan dengan penelitian ini adalah terletak pada model pembelajaran dan fokus program studinya, penelitian oleh Rama Kertamukti dengan model tatap muka di kelas dan dalam prodi Ilmu Komunikasi, sedangkam penelitian ini dengan model online/daring selama masa pandemi Covid-19 dan di dalam program studi PIAUD.

Penelitian yang dilakukan Mustaji yang Pemberdayaan mahasiswa untuk berpikir kritis, kreatif, dan kolaboratif melalui pengembangan perangkat pembelajaran kolaborasi juga menjadi acuan penelitian ini. Perangkat pembelajaran kolaborasi yang dikembangkan dapat meningkatkan kemampuan berpikir kritis, kreatif dan kolaboratif bagi mahasiswa fakultas ilmu pendidikan Universitas Negeri Surabaya. Dengan belajar secara kolaborasi, mahasiswa menjadi lebih sukses sebagai bagian dari anggota tim dan kinerja menjadi lebih berkualitas. Dari hasil temuan di lapangan, ada beberapa hal yang perlu diperhatikan kaitannya dengan pemberdayaan mahasiswa untuk berpikir kritis, kreatif, dan kolaboratif melalui pembelajaran kolaborasi yaitu, pertama agar pelaksanaan pembelajaran berjalan dengan baik mahasiswa perlu diberikan semangat dan motivasi yang kuat. Kedua, selain pemberian materi pembelajaran di kelas juga pembelajaran perlu dilakukan di luar kelas, 
misalnya melalui observasi, tugas studi kasus dan melakukan kunjungan akademik lapangan. Ketiga, dalam hal evaluasi perlu menggunakan beberapa macam evaluasi yang sesuai dengan karakteristik tiap-tiap mata kuliah (Mustaji, 2015). Perbedaan dengan penelitian ini adalah pada tempat penelitian, dalam penelitian yang dilakukan oleh Mustaji, penelitian dilaksanakan di Universitas Negeri Surabaya dalam tiga prohram studi, sedangkan peneltian ini dilaksanakan di Universitas Islam Negeri Sunan Kalijaga Yogyakarta dalam satu program studi saja.

Hasil penelitian Mubaddilah Rafa'al yang berjudul Gaya Komunikasi Dosen di Universitas : Respon Mahasiswa terhadap Gaya Komunikasi Dosen dalam Mengajar, juga menjadi rujukan bagi penelitian ini. dosen dituntut memiliki perilaku dan kemampuan yang memadai untuk menggembangkan mahasiswanya secara utuh. Untuk melaksanakan tugasnya secara baik dosen perlu menguasai berbagai hal sebagai kompetensi yang dimilikinya. Prestasi belajar itu mencerminkan keberhasilan kegiatan belajar mengajar. Dengan kata lain, berhasilnya suatu kegiatan belajar mengajar dapat dilihat dari terjadinya perubahan tingkah laku atau perilaku dari diri individu yang diwujudkan dalam sikap pengetahuan dan keterampilan yang sesuai dengan tujuan yang dirumuskan, yaitu berupa prestasi belajar (Mubaddilah Rafa'al, 2020). Perbedaan dengan penelitian ini adalah pada tempat penelitian, dalam penelitian yang dilakukan oleh Mubaddilah Rafa'al, penelitian dilaksanakan di IAIN Ternate, sedangkan penelitian ini dilaksanakan di Universitas Islam Negeri Sunan Kalijaga Yogyakarta.

Sejalan dengan informasi tersebut, penelitian mengenai strategi komunikasi dalam pembelajaran masih sedikit yang meneliti, terlebih lagi pada program studi PIAUD. Penelitian ini turut menyumbangkan suatu trobosan baru yang dapat digunakan untuk membantu permasalahan dosen dan mahasiswa saat melaksanakan pembelajaran online. Oleh karena itu tujuan dari penelitian ini adalah untuk menganalisis dan memaparkan bagaimana strategi komunikasi antara dosen dengan mahasiswa dalam mengatasi hambatan mengikuti perkuliahan online.

\section{METODOLOGI}

Penelitian ini menggunakan metode deskriptif kualitatif. Yaitu suatu strategi guna memeriksa dan mengetahui arti kelompok ataupun individu yang berkaitan pada permasalahan kemasyarakatan. Dalam penelitian menyertakan pembahasan dan proses yang terlihat, menganalisis bahan dan data dengan cara induktif, membangunnya mulai pada beberapa hal yang khusus hingga hal yanhg bersifat umum, serta peneliti membuat bentuk mengenai arti dari data yang dimaksud (Mahendra, 2020). Data diambil melalui wawancara mendalam guna mengungkapkan beberapa strategi yang digunakan mahasiswa selaku narasumber dalam memahami perkuliahan yang tersampaikan kepadanya secara online. Peneliti juga mengambil sumber data dengan dokumentasi yang berbentuk bahan dan keterangan yang diperoleh narasumber saat proses pembelajaran berlansung.

Metode studi kasus dipilih oleh peneliti dalam menyelesaikan penelitian ini. Pada hakikatnya, metode penelitian adalah suatu cara yang objektif keilmuan guna memperoleh data sesuai maksud dan tujuan tertentu. Berdasarkan pembahasannya, terdiri empat kunci yang harus cermati yakni, data, cara ilmiah, kegunaan dan tujuan . Cara ilmiah berartii bab penelitian itu harus berdasarkan pada tanda-tanda keilmuan yaitu rasional, empiris dan sistematis . Studi kasus dapat diterapkan jika suatu pertanyaan "bagaimana" dan "mengapa" ditujukan kepada beberapa kejadian saat ini yang tidak mungkin atau sukar diatur oleh peneliti. studi kasus merupakan metodologi yang dapat dipakai, apabila peneliti memiliki data yang kurang mengenai pembahasan yang ditelitinya. Berfokus pada sebuah kejadian yang sudah berlangsung, dan ada banyak sumber data. (Sugiyono, 2016) 
Peneliti mengambil dua subjek yaitu dosen dan mahasiswa, dalam penelitian ini mahasiswa Jurusan PIAUD UIN SUSKA Riau dengan matakuliah Asesmen Pembelajaran RA selaku sasaran penelitian. Peneliti memakai dua jenis sumber data yakni data primer dan data sekunder. Untuk data primer didapatkan dengan cara wawancara kepada 30 mahasiswa yang mengikuti matakuliah Asesmen Pembelajaran RA online, sedangkan untuk data sekunder diperoleh dari kajian pustaka dan literatur yang mendukung penelitian ini.

\section{HASIL DAN PEMBAHASAN}

Wawancara yang telah peniliti lakukan pada saat pembelajaran online terlaksana di jurusan PIAUD (Pendidikan Islam Anak Usia Dini) UIN SUSKA Riau mata kuliah Asesmen Pembelajaran RA. Peneliti menemukan berbagai permasalahan yang terjadi dalam pembelajaran yang berlangsung. Permasalahannya adalah ada beberapa mahasiswa yang kurang begitu memahami tentang materi pembelajaran karena terkendalanya dari sinyal yang tidak stabil, hujan yang turun secara tiba-tiba, sehingga suara dari dosen tidak terdengar dengan jelas dan kadang suara-suara dari kendaraan yang lewat juga mengganggu terhadap penerimaan materi oleh mahasiswa. Selain itu mahasiswa mengalami kejenuhan dalam mengikuti pembelajaran online. Mahasiswa yang mengalami kejenuhan dalam belajar ini tidak dapat menerima dan menampung dari materi yang disampaikan oleh dosen. Faktor yang menyebabkan yaitu trik belajar yang kurang bervariasi, sehingga dosen harus menciptakan suasana pembelajaran yang menyenangkan untuk mahasiswanya, hasil penelitian ini sejalan dengan penelitian yang dilakukan oleh Levien dan Winduwati (Levine \& Winduwati, 2021).

Mata kuliah Asesmen Pembelajaran RA pada penelitian ini, dosen menggunakan aplikasi WhatsApp dan google meet dalam melaksanakn diskusi online. Penggunaan whatsApp sebagai media pembelajaran daring sangat efektif dalam mencapai tujuan pembelajaran (Daheri et al., 2020). Dan google meet juga digunakan sebagai media pembelajaran yang dapat menunjang proses pembelajaran yang berlangsung dari rumah (Juniartini \& Rasna, 2020). Dosen telah sebaik mungkin dalam memandu perkuliahan online, dan Tentunya dengan didukung oleh kesiapan infrastruktur teknologi atau ketersediaan sistem teknologi, dan kesiapan sumber daya manusia atau mahasiswa dan dosen dalam menggunakan teknologi. (Saragih et al., 2021).

Peneliti telah melakukan wawancara kepada beberapa mahasiswa dengan menggunakan aplikasi WhatsApp mengenai pendapat mereka tentang kuliah daring mata kuliah Asesmen Pembelajaran RA, dan hasilnya sebagai berikut:

"Menurut saya dosen sebaiknya menjelaskan materinya terlebih dahulu, jadi kami tidak merasa salah dalam memahami materinya, percuma jika kami sudah menjelaskan kepada teman-teman jika ternyata jawabannya belum tepat."

Ada juga yang berpendapat seperti ini,

"Kadang materi yang di presentasikan oleh teman-teman, saya tidak begitu memahaminya, tidak ada contoh-contoh yang ditampilkan dalam presentasinya."

Terlepas dari permasalahan yang terjadi, pembelajaran online juga memiliki kelebihan mampu menumbuhkan kemandirian belajar (self regulated learning). Penggunaan aplikasi online mampu meningkatkan kemandiri belajar (Oknisih \& Suyoto, 2019). Belajar secara daring menuntut mahasiswa mempersiapkan sendiri pembelajarannya, mengevaluasi, mengatur dan secara simultan mempertahankan motiviasi dalam belajar (Anggrawan, 2019). Namun Mahasiswa juga membutuhkan penjelasan langsung dari dosen yang sudah banyak pengalamannya, dan mahasiswa butuh contoh-contoh yang konkrit sehingga mereka lebih mudah memahami materi yang disampaikan. 
Hasil wawancara lebih lanjut didapatkan peniliti, hasilnya adalah mahasiswa yang merasa bosan karena penjelasan dari teman-temannya, mereka membutuhkan penjelasan dari dosen dengan dilengkapi dengan contoh-contoh yang nyata. Oleh sebab itu sebaiknya dosen harus benar-benar menyediakan waktu diluar perkuliahan untuk menanyakan kepada mahasiswa, bagian materi mana yang belum benar-benar dikuasi oleh mahaiswa. Dosen juga harus membangun komunikasi lebih intens kepada mahasiswa, dan mempersiapkan materi-materi pembelajaran yang lebih lengkap lagi, tidak hanya teori-teori namun dengan contoh-contoh konkritnya. Sehingga mahasiswa merasa diperhatikan oleh dosen dan selama proses pembelajaran mahasiswa menjadi lebih akan lebih aktif lagi.

Mahasiswa dalam hal ini juga diharapkan untuk bisa merubah cara belajarnya secara aktif lagi, mahasiswa harus mencari referensi-referensi secara mandiri dari luar agar pengetahuan tentan materi yang diajarkan dosen mudah dipahami, sehingga tujuan pembelaran dapat berhasil. Karena Hasil belajar yang dicapai mahasiswa merupakan salah satu tolok ukur kesuksesan suatu proses pembelajaran(Fahmiati, 2014). Ada mahasiswa yang peneliti wawancarai menjawab seperti ini,

"Sebenarnya saya lebih suka pembelajaran dilakukan secara langsung, jadi saya bisa bertanya pada saat itu jika materi yang disampaiakn belum saya pahami, itulah alasan saya jika kenapa saya kurang aktif didalam perkuliahn online ini."

Jika dilihat dari pendapat mahasiswa ini, peneliti menemukan fakta yaitu komunikasi antara dosen dan mahasiswa yang terjalin secara intens dan baik sangat diperlukan sekali untuk membuat mahasiswa menjadi paham betul materi yang disampaikan, dan untuk mahasiswa yang tidak aktif bertanya pada pembelajaran online ini, mereka diharuskan setiap pertemuan mempersiapkan satu pertanyaan, sehingga dengan begitu mereka akan belajar terlebih dahulu sebelum memulai perkuliahan, dan ternyata cara ini cukup berhasil membuat mereka menjadi mahasiswa yang penuh aktif, kreatif dan inovatif, hasil ini didukung oleh penelitian yang dilakukan oleh Mustaji (2015).

Pembelajaran daring memiliki tantangan khusus, lokasi mahasiswa dan dosen yang terpisah saat melaksanakan pembelajaran menyebabkan dosen tidak dapat mengawasi secara langsung kegiatan mahasiswa selama proses pembelajaran. Tidak ada jaminan bahwa mahasiswa sunguh-sungguh dalam mendengarkan ulasan dari dosen ( Sobron, A. N. et al., 2019). Penelitian lain memberikan keterangan bahwa mahasiswa menghayal lebih sering pada perkuliahan daring dibandingkan ketika kuliah tatap muka (Firman \& Rahayu, 2020). Oleh karena itu disarankan pembelajaran daring sebaiknya diselenggarakan dalam waktu tidak lama mengingat mahasiswa sulit mempertahankan konsentrasinya apabila perkuliahan daring dilaksanakan lebih dari satu jam (Wulandari, 2021).

Penelitian dari Sadikin dan Hakim menyebutkan bahwa tidak sedikit mahasiwa yang kesulitan dalam memahami materi perkuliahan yang diberikan secara online. Bahan ajar biasa disampaikan dalam bentuk bacaan yang tidak mudah dipahami secara menyeluruh oleh mahasiswa (Sadikin \& Hakim, 2019). Dan bahan ajar yang didesain menarik dengan menyesuaikan kebutuhan mahasiswa dapat menjadi solusi permasalahan yang ada (Alqadri et al., 2021). Untuk memahami materi pada saat pembelajaran online seperti saat ini, mahasiswa dituntut selalu siap baik secara mental ataupun fisik. Disamping itu juga, faktor-faktor lain seperti stabilitas dan kecepatan jaringan, alat-alat yang dipergunakan saat belajar mengajar online, sampai memilih lingkungan yang dapat mendukung, diperlukan sekali guna memperoleh hasil yang terbaik dari proses belajar mengajar online ini. Tetapi, tidak bisa dipungkiri ada beberapa faktor yang menjadi penyebab terhambatnya proses pembelajaran. Oleh sebab itu, dosen dan mahasiswa diharapkan selalu tanggap dan penuh kesiapan untuk segala masalah-masalah yang biasa saja terjadi terkait faktor-faktor tersebut.

Faktor lain yang perlu diperhatikan dalam proses pembelajaran online adalah komunikasi dosen dengan mahasiswa, komunikasi yang efektif anatara dosen dan mahasiswa di dalam proses perkuliahan online sangat dibutuhkan untuk memperoleh 
hasil pembelajaran yang kualitas maksimal. Metode komunikasi yang baik dan tepat antara dosen dengan mahasiswa ataupun sebaliknya, masing-masing mereka tentunya memliki metode, cara, gaya atau strategi yang berbeda. Perbedaannya bisa ditelusuri dari berbagai macam pengalaman, latar belakang budaya, dan tingkat Pendidikan. Kreatif dan inovatif, itulah yang harus ada pada diri dosen dan mahasiswa saat proses perkuliahan online seperti saat ini, guna meminimalisir penghambat saat pembelajaran online terlaksana.

Setelah peneliti melakukan diskusi kepada dosen mata kuliah mengenai hasil wawancara dengan beberapa mahasiswa, peneliti melihat dosen mulai berusaha sebaik mungkin dalam pembelajaran yaitu menggunakan berbagai cara dan bentuk startegi komunikasi yang dilakukan dikaitkan dengan beberapa strategi pembelajaran yang diterapkan. Diantara penggunaan starteginya yaitu menggunakan media modul, diskusi online, kuis, tanya jawab dan yang terakhir pemberian tugas.

Strategi komunikasi yang diterapkan dalam pembelajaran online mata kuliah Asesmen Pembelajaran RA menggunakan beberapa strategi yaitu: Pertama, penggunaan metode komunikasi untuk pembelajaran, didalamya dosen mengorganisasikan pesan agar proses pembelajaran dapat berjalan secara efektif dan efisien. Pesan/ informasi diberikan secara utuh/tidak sepotong-potong, konkrit tidak abstrak, mulai dari hal-hal yang mudah/ringan, fokus tidak bertele-tele yang bisa mengakibatkat kabur isi pesan yang disampaikan, tidak mengulang-ulang isi pesan yang bisa menimbulkan pemahaman berbeda, hindari penggunaan kata-kata yang mengandung makna ganda/unsur sara, sampaikan isi pesan secara; singkat, jelas dan sederhana yang memudahkan pemahaman bagi mahasiswa.

Kedua, penggunaan media komunikasi, di dalam memilih media komunikasi perlu memperhatikan hal-hal penting yaitu: hasil komunikasi yang diharapkan, asing tidaknya bahasa yang digunakan, adanya sikap antara pribadi, rangsangan gerak dan umpan balik, rangsangan suara, dan interaksi dengan benda nyata. Jadi media komunikasi dalam pembelajaran mencakup semua sumber yang dapat dipakai untuk melakukan komunikasi pembelajaran. Ketiga, melakukan pengelolaan waktu, merupakan komponen yang cukup penting di dalam proses komunikasi, karena penggunaan waktu tidak dapat ditambah. Jadi waktu yang tersedia harus dikelola sebaik mungkin agar proses komunikasi dapat berjalan dengan efisien dan efektif. Komunikasi yang bertele-tele atau berputar-putar tidak akan memberikan pemahaman, namun komunikasi yang baik dan benar adalah proses komunikasi sesuai dengan kebutuhan. Jadi semakin pesan komunikasi dikemas dengan singkat, padat, jelas, serta sederhana jauh lebih bermanfaat.

Dosen telah merencanakan materi-materi pembelajaran dengan sangat baik. Dengan harapan dapat membuat mahasiswa bisa paham terhadap materi yang dipaparkan oleh dosennya. Dosen juga telah menyiapkan modul untuk disampaikan kepada mahasiswa, yang terdiri dari materi pokok, ringkasan materi, dan latihan soal. Semua itu digunakan untuk dapat melihat kepahaman mahasiswa dalam menerima materi yang telah disampaikan dosen. Mahasiswa juga diberi tugas oleh dosen untuk menyiapkan materi perkuliahan sesuai dengan RPP (Rancangan Pembelajaran Perkuliahan) yang dosen telah berikan, kemudian dipresentasikan di hadapan teman-temannya. Cara ini juga sebagai strategi dosen agar semua mahasiswa belajar terlebih dahulu sebelum materi tersebut dibahas dalam pembelajaran saat perkuliah perkuliahan online. Untuk materi yang memerlukan penjelasan secara mendalam, dosen dan mahasiswa yang mendapat jatah materi itu, mereka menyiapkan materi yang ditayangkan melalui video, agar kejenuhan dalam penyampaian materi dapat diminimalisir.

Selanjutnya dosen melakukan pembelajaran berbasis masalah. Dalam melakukannya, mahasiswa diminta untuk memberikan jawaban terhadap soal-soal yang diberikan mengenai materi yang dibahas agar mahasiswa bisa belajar dengan baik secara mandiri. Kadang kala, mahasiswa juga diminta untuk mempresentasikan hasil pekerjaannya di sesi perkuliahan online. Kemudian langkah yang dilakukan adalah menurunkan kecepatan 
bicara saat menyampaikan materi saat perkuliahan online. Menurunkan kecepatan bicara menjadi salah satu strategi agar penyampaian materi dapat lebih baik. Menurunkan kecepatan bicara akan memengaruhi artikulasi atau kejelasan bicara dosen sehingga diharapkan materi jadi jauh lebih jelas tersampaikan. Dosen juga harus bermain dengan dinamikan dan kekuatan suara karena ketika berbicara dengan tempo yang lebih lambat, kemungkinan mahasiswa bosan juga semakin meningkat. Dosen harus tahu kapan harus berbicara dengan penuh semangat dan kapan harus mulai menurunkan dinamika suaranya sehingga suasana belajar lebih berdinamika. Materi yang disampaikan juga harus dibungkus dengan baik dan disesuaikan dengan mahasiswa.

Untuk menghindari kejenuhan dan ketegangan dalam perkuliahan dosen menambahkan dengan memberikan nyanyian-nyanyian dan permainan-permainan yang menggugah semangat para mahasiswa untuk memulai pembelajaran. Butuh adanya komunikasi yang lebih dekat lagi antara dosen dan mahasiswa. Kolaborasi yang tepat menjadi strategi yang sangat ditekankan, dengan dosen dan mahasiswa yang bekerjasama untuk berusaha agar proses pembelajaran yang dilakukan dapat berhasil dan menjadikan mahasiswa memproleh tambahan pengetahuan dari apa yang telah sama-sama dipelajari dalam perkuliahan. Karena sejatinya dosen dan mahasiswa juga sama-sama menjalani proses belajar namun dengan cara yang berbeda.

Adanya kejelasan dalam materi yang disampaikan dan adanya contoh-contoh yang disajikan serta antusias yang ada pada dosen dan mahasiswa, akan membuat proses pemahaman dalam pembelajaran online menjadi berhasil. Ditambah jika diadakan kelas diluar jadwal perkuliahan akan membuat mahasiswa mempunyai waktu yang banyak lagi untuk menanyakan kepada dosen materi yang mana yang belum dipahaminya, sehingga semakin baik pemahaman yang didapatkan oleh mahasiswa. Hal ini juga sesuai dengan pendapat Wayne Pace, Brent D, Peterson, dan M. Dallas Burnett (dalam Miftah, 2019) yang memaparkan tujuan strategi komunikasi adalah untuk memastikan tercapainya saling pengertian antar komunikator dan komunikan, memberi pengaruh dan motivasi terhadap mahasiswa lewat pesan yang disampaikan, seta memberi gambaran tentang cara mencapai tujuan yang hendak dicapai. Pembelajaran online tidak mengharuskan dosen mengubah banyak materi. Materi bisa sama atau hampir sama dengan dengan yang ada di kelas offline dengan dimodifikasi seperti melakukan pengurangan atau penambahan substansi, bobot tugas atau materi.

\section{SIMPULAN}

Strategi komunikasi yang digunakan dosen dan mahasiswa pada jurusan PIAUD selama pembelajaran online adalah strategi kolaborasi antara dosen dan mahasiswa, dengan penggunaan metode komunikasi dan media komunikasi yang baik. Didukung dengan dosen yang secara optimal menciptakan proses pembelajaran yang aktif, inovatif dan variatif, serta dosen yang memposisikan diri sebagai motivator dan inisiator dalam pembelajaran online.

\section{UCAPAN TERIMA KASIH}

Terimakasih kepada Ibu Naimah dan Ibu Dian Tri Utami yang telah menjadi pembimbing penulisan artikel ini dan telah bersedia membiayai proses penerbitan artikel ini.

\section{DAFTAR PUSTAKA}

Alqadri, S. N. Z., Iriani, R., \& Hamid, A. (2021). Pengembangan Multimedia Pembelajaran Interaktif Menggunakan Articulate Storyline Dengan Model Pembelajaran Auditory, Intellectually Dan Repetition (AIR) Pada Materi Larutan Penyangga. JCAE (Journal of $\begin{array}{llll}\text { Chemistry and } \quad \text { Education), } & \text { 108-115. }\end{array}$ http://103.81.100.242/index.php/jcae/article/view/782 
Peningkatan Kualitas Pembelajaran Online melalui Strategi Komunikasi Efektif Selama Pandemi Covid-19 DOI: $10.31004 /$ obsesi.v6i4.1615

Anggrawan, A. (2019). Analisis Deskriptif Hasil Belajar Pembelajaran Tatap Muka dan Pembelajaran Online Menurut Gaya Belajar Mahasiswa. MATRIK: Jurnal Manajemen, Teknik Informatika Dan Rekayasa Komputer, 18(2), 339-346. https:// doi.org/10.30812/matrik.v18i2.411

Daheri, M., Juliana, J., Deriwanto, D., \& Amda, A. D. (2020). Efektifitas WhatsApp sebagai Media Belajar Daring. Jurnal Basicedu, 4(4), 775-783. https://doi.org/10.31004/basicedu.v4i4.445

Fahmiati. (2014). Peningkatan Hasil Belajar IPA Terpadu Melalui Model Pembelajaran $\begin{array}{llll}\text { Kontekstual. Jurnal Nalar } \quad \text { Pendidikan, } & \text { 2(2), }\end{array}$ http://ojs.unm.ac.id/nalar/article/view/1973

Firman, F., \& Rahayu, S. (2020). Pembelajaran Online di Tengah Pandemi Covid-19. Indonesian Journal of Educational Science (IJES), 2(2), 81-89. https://doi.org/10.31605/ijes.v2i2.659

Juniartini, N. M. E., \& Rasna, I. W. (2020). Pemanfaatan Aplikasi Google Meet dalam Keterampilan Menyimak dan Berbicara untuk Pembelajaran Bahasa pada Masa Pandemi Covid-19. Jurnal Pendidikan dan Pembelajaran Bahasa Indonesia, Vol. 9 No. 2, hal. 137. Jurnal Pendidikan Dan Pembelajaran Bahasa Indonesia, 9(2), 133-141.

Kertamukti, R. (2013). Strategi Komunikasi Antarpribadi Dosen Dan Mahasiswa Dalam Pengembangan Jiwa Kreatif. Profetik: Jurnal Komunikasi, 6(2), 27-35. http://ejournal.uin-suka.ac.id/isoshum/profetik/article/view/1167/1077

Levine, M., \& Winduwati, S. (2021). Strategi Komunikasi Dosen Perguruan Tinggi Swasta dalam Perkuliahan Daring Saat Pandemi Covid-19. Koneksi, 5(1), 157. https://doi.org/10.24912/kn.v5i1.10220

Mahendra, A. (2020). Pelaksanaan Pembelajaran Jarak Jauh Masa Pandemi Covid-19 Studi Kasus: RA Nurul Huda 01 Sumberejo Kecamatan Pabelan. http://erepository.perpus.iainsalatiga.ac.id/9806

Meidawati, Sobron A.N, Bayu, R. (2019). Persepsi Siswa Dalam Studi Pengaruh Daring Learning Terhadap Minat Belajar IPA. SCAFFOLDING: Jurnal Pendidikan Islam Dan Multikulturalisme, 1(2), 30-38. https:/ / doi.org/10.37680/scaffolding.v1i2.117

Miftah, M. (2019). Strategi Komunikasi Efektif Dalam Pembelajaran. Jurnal Teknodik, 12(2), 084. https:// doi.org/10.32550/teknodik.v12i2.473

Mubaddilah Rafa'al. (2020). Gaya Komunikasi Dosen di Universitas: Respon Mahasiswa terhadap Gaya Komunikasi Dosen dalam Mengajar. Jurnal Ilmu Komunikasi PROGRESSIO, 1(2), 66-81.

Mustaji, N. (2015). Pemberdayaan Mahasiswa Untuk Berpikir Kritis, Kreatif, Dan Kolaboratif Melalui Pengembangan Perangkat Pembelajaran Kolaborasi. Jurnal Kwangsan, 3(1), 59. https:// doi.org/10.31800/jtp.kw.v3n1.p59--76

Mutawakkil, M., \& Nuraedah, N. (2019). Gaya Komunikasi Dosen dalam Pembelajaran Mahasiswa. Communicatus: Jurnal Ilmu Komunikasi, 3(2), 25-42. https://doi.org/10.15575/cjik.v3i2.5765

Oknisih, N., \& Suyoto, S. (2019). Penggunaan Aplen (aplikasi online ) sebagai upaya kemandirian belajar siswa. Seminar Nasional Pendidikan Dasar, 477-483.

Oktaviana, M., Rahmawati, D. P., \& Sumardjijati. (2019). Strategi Mahasiswa Dalam Memahami Materi Pada Metode Pembelajaran Daring (Studi Deskriptif Kualitatif Mahasiswa Upn "Veteran" Jawa Timur Dalam Memahami Materi Pada Metode Pembelajaran Daring). Voxpop, 73-79.

Sadikin, A., \& Hakim, N. (2019). Pengembangan Media E-Learning Interaktif Dalam Menyongsong Revolusi Industri 4.0 Pada Materi Ekosistem Untuk Siswa SMA. BIODIK, 5(2), 131-138. https:/ / doi.org/10.22437/bio.v5i2.7590

Saragih, S., Markus, T., Rhian, P., \& Setiawan, S. (2021). Eksplorasi Kesiapan Dosen Dan Mahasiswa Menjalani Pembelajaran Jarak Jauh Di Masa Pandemi Covid-19. 
Kwangsan: Jurnal Teknologi Pendidikan, 9(1), 124. https:// doi.org/10.31800/itp.kw.v9n1.p124--141

Sugiyono. (2016). Metode Penelitian \& Pengembangan. Alfabeta.

Tamara, J., Sugiatno, Yanuarti, E., Warsah, I., \& Yanto, D. (2020). Strategi Pembelajaran Dosen Melalui Pemanfaatan Media Whatsapp Di Masa Pandemi COVID-19. Strategi Pembelajaran Dosen Melalui Pemanfaatan Media Whatsapp Di Masa Pandemi COVID-19, 19(2), 351-373.

Vera, N. (2020). Strategi Komunikasi Dosen Dan Mahasiswa Dalam Meningkatkan Kualitas Pembelajaran Daring Selama Pandemic Covid-19. Avant Garde, 8(2), 165. https:// doi.org/10.36080/ag.v8i2.1134

Wisman, Y. (2017). Effective Communication In Education. Jurnal Nomosleca, 3(2), 646-654. https:// doi.org/10.26905/nomosleca.v3i2.2039

Wulandari, L. (2021). Pembelajaran Daring di Masa Pandemi Covid-19 Terhadap Keberhasilan Belajar. Wawasan Pendidikan, 1(2), 135-139. https:// doi.org/10.26877/wp.v1i2.8656

Yuangga, K. D., \& Sunarsi, D. (2020). Pengembangan Media Dan Strategi Pembelajaran Untuk Mengatasi Permasalahan Pembelajaran Jarak Jauh Di Pandemi Covid- 19. JKG (Jurnal Guru Kita), 4(3), 51-58.

Yusuf Siregar, M., \& Amiril Akbar, S. (2020). Strategi guru dalam meningkatkan kualitas mengajar selama masa Pandemi COVID-19. At- Tarbawi, 12(2), 180-188. https:// doi.org/10.32505/tarbawi.v12i2.1832 